\title{
Comparing Attentional Bias for Money in Different Money Profiles Using a Cueing Paradigm*
}

\author{
ZHENG Yong \\ Southwest University, Chongqing, China
}

\author{
XU Xiaolei \\ University of Electronic Science and Technology of China, \\ Chengdu, China
}

\begin{abstract}
Four money profiles-achieving money worshiper, careless money admirer, apathetic money manager, and money-repellent individual—have been identified successfully in several studies in different countries. In the present study, attentive processing of money-related information was investigated in four groups of participants (total number $=88$ ). In an exogenous cueing paradigm, spatial attention was cued by money-related or neutral pictures that correctly or incorrectly predicted the location of a followed target. Results showed an interaction effect of picture properties and individual differences on attentional cueing. Money-related pictures were more attractive than neutral pictures to only apathetic money managers, and once they detected the money-related pictures, the attention was difficult to disengage from. This attentional bias for money-related pictures was not found in the other three money profiles.
\end{abstract}

Keywords: money profiles, attentional bias, cueing paradigm

\section{Introduction}

Money comes into being as a tool to make trade easy and its initial function is only in this. Conventional economics regard money as a convenience to facilitate exchange that has become increasingly abstract and devoid of meaning. It is ordinary, mundane, and profane and has only quantitative meaning (Belk \& Wallendorf, 1990). It is a tool to acquire commodities and services, and at the same time, it serves as a standard of value, which can be used to compare different objects (Furnham \& Argyle, 1998). Nowadays, however, money means more and more to people. It has become a utilitarian commodity that has blended into our daily lives (Furnham \& Lewis, 1986). The meaning of money varies with each individual. It may be a motivator for some people to work hard (Lawler, 1981; McClelland, 1967), but to others, it is probably just a hygiene factor (Herzberg, Mausner, \& Snyderman, 1959). Money influences people’s attitudes and satisfaction toward work (Luna-Arocas \& Tang, 2004; Tang \& Gilbert, 1995), helping behaviors and social influence (Liu, Smeesters, \& Vohs, 2012; Tang, Sutarso, Davis, Dolinski, Ibrahim, \& Wagner, 2007; Vohs, Mead, \& Goode, 2008; Yang, Wu, Zhou, Mead, Vohs, \& Baumeister, 2013), unethical behavior (Du \& Tang, 2011; Tang \& Chen, 2007), and

\footnotetext{
*Acknowledgments: This work is supported by the MOE Project of Key Research Institute of Humanities and Social Sciences at Universities, China (\#15JJDZONGHE022).

ZHENG Yong, Ph.D., Professor, Center for Studies of Education and Psychology of Ethnic Minorities in Southwest China, Southwest University.

XU Xiaolei, Research Assistant, School of Life Science and Technology, University of Electronic Science and Technology of China.
} 
subjective well-being (Diener, Tay, \& Oishi, 2013; Headey \& Wooden, 2012; Stevenson \& Wolfers, 2013; Tatzel, 2002), and it can reduce feelings of physical pain through priming money concept (Zhou, Vohs, \& Baumeister, 2009). Some people even behave toward money as if it were a drug rather than a tool (Lea \& Webley, 2006). Thus, it can be seen that money is no longer just a means of exchange and that its function has already extended into many other aspects.

As people have to contact with money, they have developed different attitudes and behavioral tendencies toward it (Mitchell \& Mickel, 1999). People's attitudes toward money, especially as expressed in monetary habits and beliefs, are affected by primary and secondary socialization. In childhood, parents' income and education no doubt determine children's spending and saving habits, but as children grow up and accept higher education and as their needs change, some changes in beliefs and habits about money occur (Furnham, 1984). A review of previous studies regarding attitudes toward money shows that there are significant differences in money attitudes between different populations (Luna-Arocas \& Tang, 2004; Tang \& Chen, 2007). Several questionnaires have been developed to measure people's money attitudes, but only three measures are well-developed and have been used systematically (Mitchell \& Mickel, 1999): the Money Ethic Scale (Tang, 1992; 1993; 1995), the Money Importance Scale (Mitchell, Dakin, Mickel, \& Gray, 1998), and the Money Belief and Behavior Scale (Furnham, 1984; Roberts \& Jones, 2001).

People's money attitudes are studied mostly through questionnaires and surveys. Tang and his associates identified four money profiles using the Money Ethic Scale: achieving money worshiper, careless money admirer, apathetic money manager, and money-repellent individual (Du \& Tang, 2003; 2011; Tang, T. L. P., Tang, D. S. H., \& Luna-Arocas, 2005). They found some differences between the four money profiles, such as job satisfaction (T. L. P. Tang, T. L. N. Tang, \& Luna-Arocas, 1999) and self-value (Du \& Tang, 2003). However, all the differences were detected through questionnaires, and no experimental literature related to the differences between these four money profiles has yet been published. In this study, we hope to supplement this lack.

In the current study, we aimed to research the different attentional biases for money between the four money profiles. To achieve this objective, the Money Ethic Scale (MES) was used to identify the four money profiles. Then, two categories of pictures-money-related and neutral-were presented in an exogenous cueing paradigm (Posner, 1980). In this task, participants were asked to judge the location of the target, which might appear on the left or right side of a fixation cross. In $75 \%$ of the trials, the peripheral cue stimuli preceded the target at the same spatial location ("valid" trials). In the remaining 25\%, targets were presented at the opposite spatial location of the cue stimuli (“invalid” trials). In valid trials, exogenous cue stimuli could facilitate responding to the target, whereas in invalid trials, a longer target reaction time is observed. This pattern demonstrates the so-called "cue validity effect". We hypothesize that the attentional bias to money would be different for different money profiles, and that at least one group would show attention vigilance to money-related pictures. This means that, under valid cue conditions, their responses to money-related pictures would be faster than to neutral pictures. Attention would be maintained on money-related pictures longer than neutral pictures, which means that attention on money-related pictures would be more difficult to disengage from after they have been detected. We hope to find which money-related information is more attractive to money profiles through experimental study. 


\section{Method}

\section{Participants}

A 58-item questionnaire was distributed to undergraduate students attending Southwest University, in China. A total of 229 (75 men and 154 women) valid questionnaires were retrieved, and 191 subjects voluntarily left their contact information. Subjects’ ages ranged from 18 to 24, with a mean age of 20.6. None of them had prior full-time job experiences. Subjects were split into four money profiles based on the cluster analysis conducted in SPSS 16.0.

Subjects for the following experiment were recruited from the four clusters by telephone. Finally, 88 subjects, including 22 apathetic money managers, 24 careless money admirers, 20 achieving money worshipers, and 22 money-repellent individuals, were interested and had enough time to take part in the present experiment.

\section{Materials}

Questionnaire. Students' attitudes toward money were assessed with the Chinese translation of the MES (Tang, 1992). The MES consists of three dimensions: cognition, emotion, and behavior. Tang and his associates have developed different versions of the MES (Du \& Tang, 2005; Luna-Arocas \& Tang, 2004; Tang, 1993; 1995) in accordance with the ABC model of attitude (Ajzen \& Fishbein, 1977). The MES is well-developed and has been used systematically (Mitchell \& Mickel, 1999; Tang et al., 2005), its Chinese translation has been demonstrated to have the same dimension as the original MES and has successfully been used to identify money profiles in Chinese samples (Du \& Tang, 2003; 2011). The Chinese MES version used in this study has 58 items, through exploratory factor analysis of the questionnaire data and using varimax rotation, a scree-text and a criterion of eigenvalues greater than one, 31 items were preserved, and 9 factors were selected including 5 cognitive factors (motivator, respect, achievement, equity, and power), 2 emotional factors (good and evil), and 2 behavior factors (budget and donation). The Cronbach's alpha for each of the 9 factors was as followed: 0.85 (motivator), 0.82 (respect), 0.81 (achievement), 0.75 (equity), 0.75 (power), 0.84 (good), 0.79 (evil), 0.82 (budget), and 0.77 (donation). The Cronbach's alpha of the scale was 0.80, suggesting that the scale has good reliability. Using a cluster analysis program, four clusters of data were identified: careless money admirer (20.5\%), apathetic money manager (39.3\%), achieving money worshiper (15.7\%), and money-repellent individual (24.5\%). The character of each cluster is shown in Table 1.

Table 1

Means (Standard Deviations) of the Nine Factors for Four Clusters

\begin{tabular}{|c|c|c|c|c|}
\hline & $\begin{array}{l}\text { Cluster } 1 \\
\text { Careless } \\
\text { money admirer } \\
n=47 \\
(20.5 \%)\end{array}$ & $\begin{array}{l}\text { Cluster } 2 \\
\text { Apathetic } \\
\text { money manager } \\
n=90 \\
(39.3 \%)\end{array}$ & $\begin{array}{l}\text { Cluster } 3 \\
\text { Achieving } \\
\text { money worshiper } \\
n=36 \\
(15.7 \%)\end{array}$ & $\begin{array}{l}\text { Cluster } 4 \\
\text { Money-repellent } \\
\text { individual } \\
n=56 \\
(24.5 \%)\end{array}$ \\
\hline Motivator & $14.94(2.08)$ & $19.29(2.21)$ & $23.36(2.06)$ & $19.27(2.36)$ \\
\hline Respect & $9.51(2.68)$ & $13.11(1.96)$ & 13.72 (2.89) & $8.86(2.67)$ \\
\hline Achievement & $6.74(2.03)$ & $8.73(2.31)$ & $10.78(2.52)$ & $5.40(1.72)$ \\
\hline Equity & $8.77(2.12)$ & $10.67(1.79)$ & $8.36(2.30)$ & $8.35(2.46)$ \\
\hline Power & 4.83 (1.49) & $6.47(1.42)$ & 7.67 (1.99) & 5.27 (1.68) \\
\hline Good & $16.87(2.61)$ & $20.60(2.22)$ & $24.39(1.25)$ & 20.45 (2.19) \\
\hline Evil & $9.30(2.46)$ & $8.03(2.31)$ & $7.83(3.44)$ & $9.55(2.90)$ \\
\hline Budget & $10.60(2.63)$ & $11.28(2.21)$ & $10.56(2.60)$ & $9.48(2.77)$ \\
\hline Donation & $10.91(1.67)$ & $10.58(1.75)$ & $10.06(2.91)$ & 10.64 (1.99) \\
\hline
\end{tabular}

Note. The highest and the lowest means are in boldface and the lowest means are italicized. 
Pictorial stimuli. Twenty pictures were used as stimuli, including 10 money-related pictures taken by a digital camera, and 10 neutral pictures (white cup) collected from the Internet. In the present study, only the largest Chinese RMB denomination (¥100) was used. All pictures were adjusted to the same size $(200 \times 300$ pixels) with a black background using Adobe Photo shop.

Attentional task. E-Prime version 1.1 was used to program and present the cueing paradigm task. The program ran on a Windows XP PC, and all stimuli were presented on a 17-in-monitor.

Each trial began with the presentation of two white frames $\left(200 \times 300\right.$ pixels, subtending $9.5^{\circ} \times 9.5^{\circ}$ of the visual angle), which were situated on the left and right sides of a fixation cross. The distance between the center of one of the white frames and the fixation cross was 90 pixels. The background color of the screen was set to black. The two white frames remained on screen throughout the entire trial. After $750 \mathrm{~ms}$, a picture was presented for $250 \mathrm{~ms}$, filling one of the two frames. Next, the picture disappeared, and the two frames remained for $50 \mathrm{~ms}$ in order to avoid impaired target detection by after-effects of the picture. After that, the target, a white-colored dot (diameter was 10 pixels), appeared in the center of one frame until the participant responded. Once the participant responded, or after 3,000 ms without response, the next trial started immediately (see Figure 1).

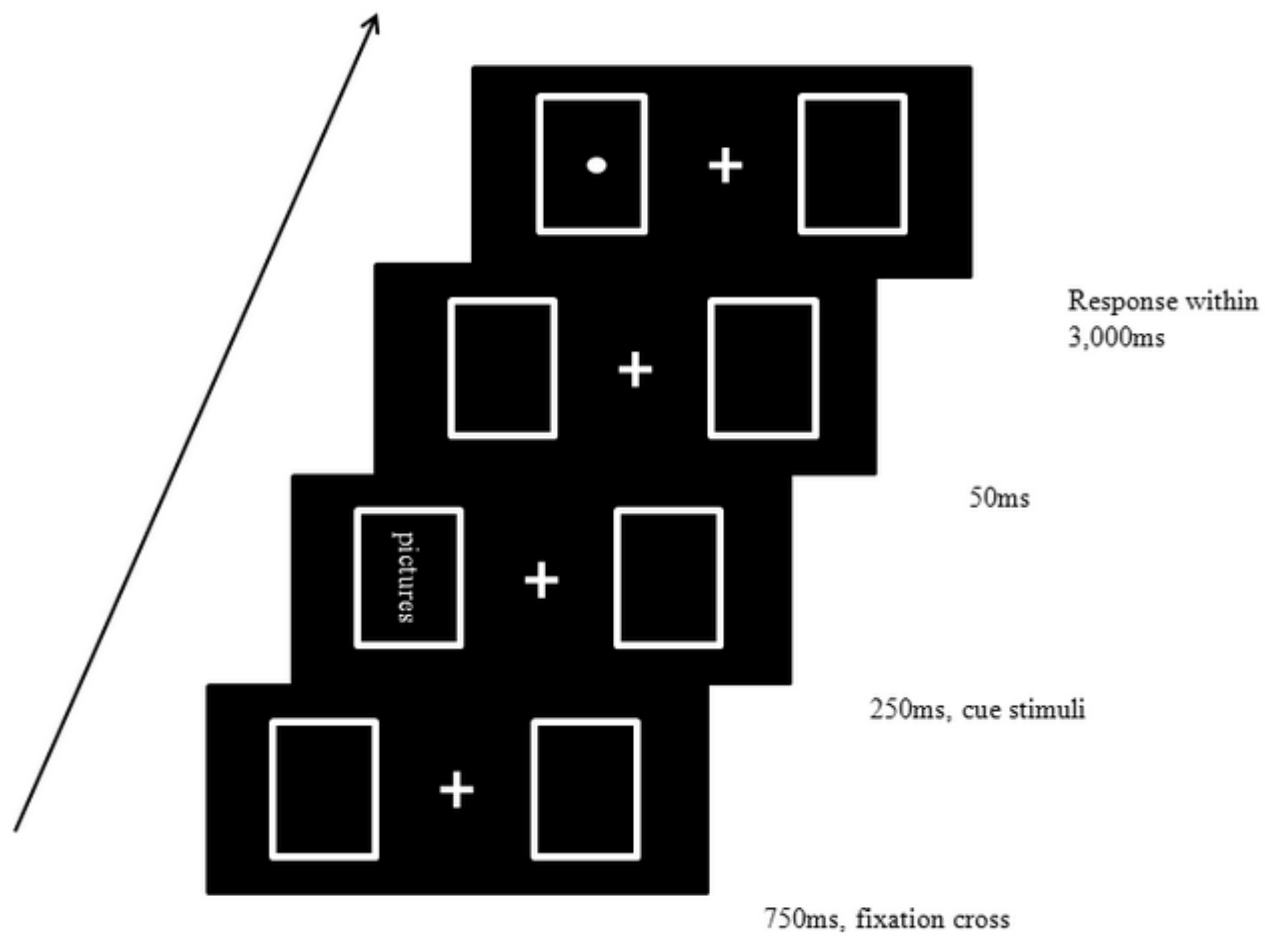

Figure 1. A procedure of a valid trial.

All participants first completed 32 practice trials (the pictures were unrelated to the test pictures) followed by 3 test blocks, each consisting of 160 trials (each of the 20 pictures was presented 8 times in one block). For one block, there were 120 (75\%) valid trials (targets and cue stimuli appeared in the same frame) and 40 (25\%) invalid trials (targets and cue stimuli appeared in different frame). Within trials, money-related and neutral pictures were presented randomly and appeared equally as often on the left and right frames. Valid and invalid trials were presented randomly throughout the experiment. Therefore, in this experiment, every picture was 
presented in 24 trials including 18 valid trials (9 in the left and 9 in the right) and 6 invalid trials ( 3 in the left and 3 in the right).

\section{Procedure}

This experiment was completed in separate computer testing rooms that were $2 \mathrm{~m}^{2} \times 3 \mathrm{~m}^{2}$ each. The distance between the computer screen and the seat was $60 \mathrm{~cm}$. All participants were instructed to respond as accurately and quickly as possible to the target on the screen by pressing two keys on a standard keyboard (if the target appeared in the left frame, press "F" if it appeared in the right frame, press "J"). Participants were tested in groups of 7 . When the experiment started, they were asked to work as quietly as possible.

\section{Results}

\section{Data preparation}

All trials were excluded in which no response occurred, the answer was wrong, or RT was below $100 \mathrm{~ms}$ or above $1000 \mathrm{~ms}$. Data from one participant was deleted as the accuracy rate was below $80 \%$. Accuracy rate data on money-related and neutral pictures as cue stimuli trials for the four clusters are shown in Table 2.

Table 2

Means (Standard Deviations) of Accuracy Rate for the Target Identification of Money-Related and Neutral Cue Pictures of Each Cluster

\begin{tabular}{lll}
\hline & Money-related ACC (\%) & Neutral ACC (\%) \\
\hline Careless money admirer & $98.82(0.02)$ & $98.45(0.02)$ \\
Apathetic money manager & $98.05(0.02)$ & $97.86(0.02)$ \\
Achieving money worshiper & $98.47(0.03)$ & $98.21(0.03)$ \\
Money-repellent individual & $98.27(0.02)$ & $98.32(0.03)$ \\
\hline
\end{tabular}

Note. ACC-accuracy rate.

\section{Correlational analyses}

Results were analyzed in a 2 (picture property: money-related vs. neutral) $\times 4$ (group: careless money admirer vs. apathetic money manager vs. achieving money worshiper vs. money-repellent individual) $\times 2$ (cue validity: valid vs. invalid) repeated measures ANOVA. The main effects of picture property and group were not significant, $F(1,83)=0.53, p>0.05 ; F(3,83)=2.15, p>0.05$. While the main effect of cue validity was significant, $F(1,83)=649.59, p<0.01$. RT in invalid cue condition $(M=375.22 \mathrm{~ms})$ was much higher than that in valid cue condition ( $M=306.81 \mathrm{~ms})$. Mean RT of different pictures in four groups in valid and invalid conditions were presented in Table 3. Moreover, a significant group $\times$ picture property $\times$ cue validity interaction was found, $F(3,83)=10.55, p<0.01$, see Table 4 .

Table 3

Mean Reaction Times (ms) of Money-Related and Neutral Cue Pictures in Valid and Invalid Conditions in Four Groups

\begin{tabular}{lllll}
\hline & \multicolumn{2}{l}{ Money-related pictures } & \multicolumn{2}{l}{ Neutral pictures } \\
\cline { 2 - 5 } & Valid & Invalid & Valid & Invalid \\
\hline Careless money admirer & 318.00 & 395.59 & 315.25 & 398.17 \\
Apathetic money manager & 301.01 & 374.86 & 305.33 & 364.57 \\
Achieving money worshiper & 305.65 & 369.18 & 303.82 & 371.85 \\
Money-repellent individual & 301.65 & 364.29 & 303.76 & 363.23 \\
Total & 306.58 & 375.98 & 307.04 & 374.46 \\
\hline
\end{tabular}


Table 4

The Interaction Result of 4 (Group) $\times 2$ (Picture Property) $\times 2$ (Cue Validity)

\begin{tabular}{llllll}
\hline & Validity & Picture property & Mean difference & Std. error & Sig. \\
\hline \multirow{2}{*}{ Careless money admirer } & 1 & 12 & 2.76 & 1.65 & 0.098 \\
& 2 & 12 & -2.59 & 2.37 & 0.279 \\
\hline \multirow{2}{*}{ Apathetic money manager } & 1 & 12 & -4.32 & 1.58 & $0.007^{* *}$ \\
& 2 & 12 & 10.28 & 2.27 & $0.000^{* *}$ \\
\hline \multirow{2}{*}{ Achieving money worshiper } & 1 & 12 & 1.84 & 1.77 & 0.302 \\
& 2 & 12 & -2.67 & 2.55 & 0.299 \\
\hline \multirow{2}{*}{ Money-repellent individual } & 1 & 12 & -2.12 & 1.65 & 0.202 \\
& 2 & 12 & 1.06 & 2.37 & 0.655 \\
\hline
\end{tabular}

Notes. Validity: 1 = valid; 2 = invalid; Picture property: 1 = money-related pictures; 2 = neutral pictures; ** $p<0.01$.

Under the valid cue stimuli condition, a 4 (group) $\times 2$ (picture property) repeated measures ANOVA was performed to examine any main or interaction effects. This analysis revealed only an interaction effect of groups and picture property, $F(3,83)=4.16, p<0.01$. Post Hoc Multiple Comparisons analysis indicated that only to the apathetic money manager, the mean RT responded to money-related pictures ( $M=301.01 \mathrm{~ms})$ was significantly faster than that responded to neutral pictures $(M=305.33 \mathrm{~ms})$. There were no significant differences in the mean RTs responded to the targets followed by money-related and neutral cue pictures in the other three groups.

Under the invalid cue stimuli condition, the same analytical method was performed to the data. Result showed a main effect of group, $F(3,83)=3.03, p<0.05$. Careless money admirer responded strikingly slower $(M=396.88 \mathrm{~ms})$ than the other three groups $(M=369.72 \mathrm{~ms}, 370.52 \mathrm{~ms}$, and $363.76 \mathrm{~ms}$, apathetic money manager, achieving money worshiper, and money-repellent individual, respectively). The interaction effect of group and picture property was significant, $F(3,83)=6.84, p<0.01$. Comparing the mean RT responded to the targets followed by money-related and neutral cue pictures, only the apathetic money manager responded to money-related cue pictures ( $M=374.86 \mathrm{~ms}$ ) slower than to neutral cue pictures ( $M=364.57 \mathrm{~ms}$ ), see Figure 2 .

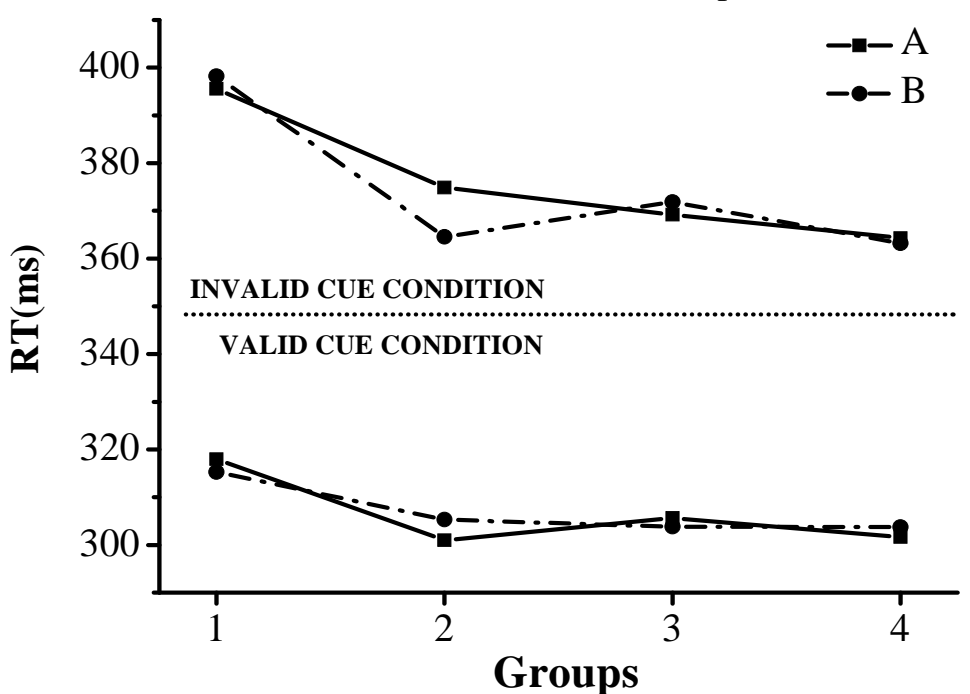

Figure 2. Comparison of RT responded to money-related and neutral pictures in valid and invalid cue conditions for four groups.

Notes. Groups: 1 = Careless money admirer; 2 = Apathetic money manager; 3 = Achieving money worshiper; $4=$ Money-repellent individual. A = Money-related pictures; B = Neutral Pictures. 


\section{Discussion}

Previous studies revealed that, for Chinese students, apathetic money manager formed the largest cluster (31.5\%) (Du \& Tang, 2003). In this questionnaire survey, the largest cluster was also apathetic money manager (39.3\%). However, there were some differences in the sizes of these four clusters in different studies (Luna-Arocas \& Tang, 2004; Tang et al., 2005). This might be related to participants’ differing family income, economic levels, hometowns, and cultures, as explained by Tang et al. (2005).

Apathetic money managers (the largest cluster) in this study had the highest scores for the factors motivator, equity, and budget and tended to have moderate scores for the other factors. In general, apathetic money managers can be motivated by money, and they budget their money carefully. Money-repellent individuals (the second largest group) obtained the highest score for the factor evil and the lowest scores for the factors respect, achievement, equity, and budget. Thus, these individuals had the most negative money attitudes. Careless money admirers (the third largest group) had the lowest scores for the factors motivator, power, and good and the highest score for factor donation. They might be more likely to do charity work with their money as money cannot motivate them and is not important in their eyes. Achieving money worshipers (the smallest cluster) had the highest scores for the factors respect, achievement, power, and good and the lowest scores for the factors evil and donation. These individuals had the most positive attitudes toward money (Tang et al., 2005). There was a striking difference in money attitudes between the four clusters, because the cluster analysis program (SPSS 16.0) had chosen to maximize the differences between cases in different clusters. The present study further investigated the difference between these four money profiles in dealing with specific and direct money information. This is the first attempt to research this difference through experimentation.

This experiment investigated attentional bias for money information in the four money profiles. Only the apathetic money manager profile shows biased attention toward money-related picture stimuli. Under the valid cue condition, participants in the apathetic money manager profile responded to the target followed by money-related cue pictures significantly faster than to neutral cue pictures, indicating that the component of the attention bias is attention vigilance. This means that money-related information attracts the attention of this group of individuals more easily. On the contrary, under the invalid condition, their response to the target followed by money-related cue pictures was significantly slower than to the neutral cue pictures, indicating that attention maintenance is a salient attention bias in this group. That is, money-related information is difficult to disengage from after it has been detected. The result is consistent with our hypothesis that at least 1 of the 4 money profiles would show attentional bias for money-related information.

In this study, all participants were undergraduate students who had no full-time job experience, and most of them were expected to not fully understand the importance of money in real lives and not just on consciousness. These participants' expenses came from their families, and were not something they needed to worry about; therefore, there may be little difference between money and other neutral items, such as cups, in their eyes. However, for apathetic money managers, it is probable that they have more profound cognition of money as they budget their money more carefully and are more likely to be motivated by money in their future endeavors. This may be an important reason for the difference between apathetic money managers and all other groups. It is likely the reason for their tendency to be more easily attracted to money-related pictures and to find it more difficult to disengage from them. 
There are several limitations in this study. First, we did not collect the demographic characteristics of the participants, such as major, family economic status, and parents' educational background, which were important factors in forming individuals' money attitudes. Second, only the highest par value of the RMB (¥100) was used in this study. The color of the $¥ 100$ note is mostly red with a small fraction of white while its counterpart was a white cup; therefore, the color might have somehow affected the results. However, if this were so, then the factor of color would have influenced all four groups of participants, so it is hard to attribute this factor as the main reason for the result. Third, even if a significant difference in attentional bias for money between the four money profiles had been found in this study, the result would not apply directly to real life, such as in recruiting practice. Many other factors should be taken into account.

Further studies need to be conducted in the future regarding the differences between these four money profiles. Previous research has suggested that money attitudes are different between full-time employees, part-time employees, and non-employed students (Tang, Kim, \& Tang, 2002). Hence, results might be different if participants were individuals who had worked for many years; or who had only had part-time jobs in the past. In addition, as the literature indicates that people in different countries have different money attitudes (Tang, Furnham, \& Davis, 2000), there might be some differences between people who grew up in collectivistic societies and in individualistic communities; or between individuals living in developing countries and those in developed countries.

\section{References}

Ajzen, I., \& Fishbein, M. (1977). Attitude-behavior relations: A theoretical analysis and review of empirical research. Psychological Bulletin, 84, 888-918.

Belk, R. W., \& Wallendorf, M. (1990). The sacred meanings of money. Journal of Economic Psychology, 11, 35-67.

Diener, E., Tay, L., \& Oishi, S. (2013). Rising income and the subjective well-being of nations. Journal of Personality and Social Psychology, 104, 267-276.

Du, L., \& Tang, T. L. P. (2003). Money profiles and self-value: An investigation of the money ethic endorsement of university students in China. Psychological Science, 26, 915-916.

Du, L., \& Tang, T. L. P. (2005). Measurement invariance across gender and major: The love of money among university students in People's Republic of China. Journal of Business Ethics, 59, 281-293.

Du, L., \& Tang, T. L. P. (2011). Money profiles and unethical activity: An investigation of the money ethic endorsement of managerial staffs in China. Modern Management, 1, 156-160.

Furnham, A. (1984). Many sides of the coin: The psychology of money usage. Personality and Individual Differences, 5, 501-509.

Furnham, A., \& Argyle, M. (1998). The psychology of money. London: Routledge.

Furnham, A., \& Lewis, A. (1986). The economic mind: The social psychology of economic behavior. Brighton: Wheatsheaf.

Headey, B., \& Wooden, M. (2012). The importance of wealth for subjective well-being. Journal of Financial Transformation, 15, 59-67.

Herzberg, F., Mausner, B., \& Snyderman, B. B. (1959). The motivation to work. New York: Wiley.

Lawler, E. E. (1981). Pay and organization development. Reading, MA: Addison-Wesley.

Lea, S. E., \& Webley, P. (2006). Money as tool, money as drug: The biological psychology of a strong incentive. Behavioral and Brain Sciences, 29, 161-175.

Liu, J. E., Smeesters, D., \& Vohs, K. D. (2012). Reminders of money elicit feelings of threat and reactance in response to social influence. Journal of Consumer Research, 38, 1030-1046.

Luna-Arocas, R., \& Tang, T. L. P. (2004). The love of money, satisfaction, and the protestant work ethic: Money profiles among univesity professors in the USA and Spain. Journal of Business Ethics, 50, 329-354.

McClelland, D. C. (1967). Money as a motivator: Some research insights. The McKinsey Quarterly, 4, 10-21. 
Mitchell, T. R., Dakin, S., Mickel, A., \& Gray, S. (1998). The measurement of money importance. Paper presented at the Annual Meeting of the Academy of Management, San Diego, CA.

Mitchell, T. R., \& Mickel, A. E. (1999). The meaning of money: An individual-difference perspective. Academy of Management Review, 24, 568-578.

Posner, M. I. (1980). Orienting of attention. Quarterly Journal of Experimental Psychology, 32, 3-25.

Roberts, J. A., \& Jones, E. (2001). Money attitudes, credit card use, and compulsive buying among American college students. Journal of Consumer Affairs, 35, 213-240.

Stevenson, B., \& Wolfers, J. (2013). Subjective well-being and income: Is there any evidence of satiation? National Bureau of Economic Research, w18992.

Tang, T. L. P. (1992). The meaning of money revisited. Journal of Organizational Behavior, 13, 197-202.

Tang, T. L. P. (1993). The meaning of money: Extension and exploration of the money ethic scale in a sample of university students in Taiwan. Journal of Organizational Behavior, 14, 93-99.

Tang, T. L. P. (1995). The development of a short money ethic scale: Attitudes toward money and pay satisfaction revisited. Personality and Individual Differences, 19, 809-816.

Tang, T. L. P., \& Chen, Y. J. (2007). Intelligence vs. wisdom: The love of money, machiavellianism, and unethical behavior across college major and gender. Journal of Business Ethics, 82, 1-26.

Tang, T. L. P., Furnham, A., \& Davis, G. M. T. W. (2000). A cross cultural comparison of pay differentials as a function of rater's sex and money ethic endorsement: The Matthew effect revisited. Personality and Individual Differences, 29, 685-697.

Tang, T. L. P., \& Gilbert, P. R. (1995). Attitudes toward money as related to intrinsic and extrinsic job satisfaction, stress and work-related attitudes. Personality and Individual Differences, 19, 327-332.

Tang, T. L. P., Kim, J. K., \& Tang, T. L. N. (2002). Endorsement of the money ethic, income, and life satisfaction: A comparison of full-time employees, part-time employees, and non-employed university students. Journal of Managerial Psychology, 17, 442-467.

Tang, T. L. P., Sutarso, T., Davis, G. M. T. W., Dolinski, D., Ibrahim, A. H. S., \& Wagner, S. L. (2007). To help or not to help? The good samaritan effect and the love of money on helping behavior. Journal of Business Ethics, 82, 865-887.

Tang, T. L. P., Tang, D. S. H., \& Luna-Arocas, R. (2005). Money profiles: The love of money, attitudes, and needs. Personnel Review, 34, 603-618.

Tang, T. L. P., Tang, T. L. N., \& Luna-Arocas, R. (1999). Money profiles as related to work-related attitudes: An examination of the money ethic endorsement among citizens in the USA. Paper presented at the 6th European Congress of Psychology, Rome, Italy.

Tatzel, M. (2002). “Money worlds” and well-being: An integration of money dispositions, materialism and price-related behavior. Journal of Economic Psychology, 23, 103-126.

Vohs, K. D., Mead, N. L., \& Goode, M. R. (2008). Merely activating the concept of money changes personal and interpersonal behavior. Current Directions in Psychological Science, 17, 208-212.

Yang, Q., Wu, X., Zhou, X., Mead, N. L., Vohs, K. D., \& Baumeister, R. F. (2013). Diverging effects of clean versus dirty money on attitudes, values, and interpersonal behavior. Journal of Personality and Social Psychology, 104, 473-489.

Zhou, X., Vohs, K. D., \& Baumeister, R. F. (2009). The symbolic power of money reminders of money alter social distress and physical pain. Psychological Science, 20, 700-706. 